\title{
Paolo SINISCALCO, Starożytne Kościoly wschodnie. Historia i literatura, tlum. Katarzyna Piekarz, Kraków 2013, Wydawnictwo PETRUS, ss. 296.
}

Wśród literatury historycznej rzadko można spotkać książki przedstawiające skondensowaną i podaną w przystępny sposób historię Kościołów wschodnich. Tę lukę na rynku wydawniczym uzupełnia książka Paolo Siniscalco w thumaczeniu Katarzyny Piekarz: Starożytne Kościoły wschodnie. Historia i literatura. Jest to cenna pozycja, chociażby z tego względu, że oprócz historii poszczególnych Kościołów Wschodu czytelnik może również zapoznać się z najważniejszą spuścizną tychże wspólnot $-\mathrm{z}$ ich literaturą. Autor pisząc tę książkę zaprosił do współpracy specjalistów - znawców literatury orientalnej. Są nimi: Michel van Esbroeck, Rene Lavenant, Paolo Marrassini i Tito Orlandi. Książka jest podzielna na 14 rozdziałów. Cenną rzeczą tego opracowania jest również to, że na końcu każdego rozdziału zamieszczono bardzo bogatą bibliografię, dotyczącą historii i literatury poszczególnych Kościołów, wśród której znajdują się również pozycje w języku polskim.

Paolo Siniscalco w przedmowie do wydania polskiego (s. 5-19) podejmuje się ogólnego wyjaśnienia kwestii Kościołów wschodnich. Pisze o różnorodności Wschodu (s. 5-6), tłumaczy pojęcie chrześcijańskiego Wschodu (s. 7) oraz przedstawia spory doktrynalne V-VI w. w kontekście pluralizmu w Kościołach wschodnich i sytuacji chrześcijańskiego Wschodu pod panowaniem islamskim (s. 7-11). Cenną rzeczą tej przedmowy - jak na początku pisze sam Autor - jest ukazanie obecnego kształtu poszczególnych Kościołów oraz exodusu chrześcijan ze Środkowego Wschodu (s. 11-18).

W rozdziale I (s. 33-49), którzy można nazwać wprowadzającym, Paolo Siniscalco pisze o Kościele i Kościołach w wymiarze uniwersalnymi i lokalnym, podejmuje kwestię używanych języków (s. 40-44) oraz form liturgicznych (s. 4449). Swoje rozważania Autor wyprowadza z Nowego Testamentu i prowadzi poprzez teksty pisarzy wczesnochrześcijańskich.

Rozdział II przedstawia Kościół jerozolimski (s. 50-67) jako najstarszy i jeden z najbardziej uprzywilejowanych. Autor na początku pokrótce prezentuje historię Swiętego Miasta (s. 50-55), jego - jak sam określa - „chrześcijańskie narodziny” (s. 55-58), dokonuje charakterystyki tego Kościoła i przedstawia biskupów Jerozolimy (s. 58-62). Zbyt krótko, choć nie należy to do istoty tematu, zostały przedstawione losy Świętego Miasta i jego Kościoła po VII w. Pobieżnie też zaprezentowano aktualną sytuację (s. 62-65).

Rozdział III poświęcony jest chrześcijańskiemu Egiptowi (s. 68-88). Jak na początku pisze Paolo Siniscalco „wkład Egiptu w rozwój chrześcijaństwa w pierwszych wiekach naszej ery jest wyjątkowy. Obszar na którym rozwija się przesłanie Chrystusa, jak powszechnie wiadomo, ma szczególną historię. Stanowi on kolebkę cywilizacji, która rozkwitła w epoce faraonów, a następnie rozwijała się w okresie hellenistycznym i rzymskim" (s. 68). Dużo uwagi Autor poświęca ośrodkowi aleksandryjskiemu (s. 73-78) oraz monastycyzmowi (s. 78-82), który 
zrodził się w Egipcie. Pokrótce również przedstawia historię Kościoła na terenie starożytnego Egiptu pod dominacją muzułmańskich Arabów, aż po czasy współczesne (s. 82-85).

Autorem rozdziału IV jest Tito Orlandi. Pisze on o literaturze koptyjskiej i historii chrześcijańskiego Egiptu. Jak sam tłumaczy, „narodziny i rozwój literatury koptyjskiej są ściśle związane z sytuacja historyczną towarzyszącą rozwojowi Kościoła chrześcijańskiego w Egipcie" (s. 89). W interesujący sposób Autor łączy rozwój literatury koptyjskiej z monastycyzmem egipskim (s. 92-97). Bardzo dużo uwagi poświęca sporom orygenesowskim (s. 97-104). Bogactwem tego rozdziału jest ukazanie wielkiego wpływu historii oraz polityki na kształtowanie się literatury chrześcijańskiej.

Rozdział V traktuje o Kościele etiopskim (s. 117-132). Paolo Siniscalco podobnie jak w poprzednich rozdziałach - zaczyna od krótkiego przedstawienia tła historycznego przed pojawieniem się chrześcijaństwa, zwracając szczególną uwagę na Salomona, królowę Sabę i królewski ród etiopski (s. 117-118) oraz na nawrócenie Etiopczyka przez apostoła Filipa (s. 118-119). Walorem tego rozdziału jest ukazanie kształtowania się Kościoła koptyjskiego w relacji do Syrii oraz Egiptu hellenistycznego i koptyjskiego (s. 121-124). Uzupełnieniem prezentowanych treści jest rozdział VI autorstwa Paolo Marrassiniego, który traktuje o literaturze etiopskiej (s. 133-144).

Rozdział VII traktuje o Kościele Zachodniosyryjskim (s. 145-166). Autor, oprócz historii przyjęcia chrześcijaństwa, przedstawia wielkie spory doktrynalne V w. oraz ich inicjatorów (s. 153), a także konflikt, jaki w tym czasie miał istniał pomiędzy Antiochią i Aleksandrią (s. 157-158). W końcowej części rozdziału mówi o rozwiązaniu omawianych problemów (s. 159-161).

W rozdziale VIII bardzo szczegółowo przedstawiona jest przez Rene Lavenanta wczesna literatura syryjska (s. 167-192). Autor w interesujący sposób prezentuje najpierw literaturę przedchrześcijańską (s. 169-171), a następnie zapoznaje czytelnika z konkretnymi dziełami chrześcijańskimi, pokrótce je omawiając.

Niestety, zbyt krótko i ogólnie, moim zdaniem, zostali przedstawieni maronici (rozdział IX, s. 193-198). Przecież w ostatnim czasie, również w Polsce, wspólnota ta cieszy się szczególnym zainteresowaniem, chociażby ze względu na św. Charbela, maronickiego mnicha.

W rozdziale X Paolo Siniscalco prezentuje Kościół asyryjski, który inaczej nazywany jest Kościołem wschodniosyryjskim (s. 199-214). Mocną stroną tego rozdziału jest przedstawienie herezji, które wyrosły z tej wspólnoty i trwanie ich skutków aż do czasów współczesnych.

Rozdział XI opisuje historię Kościoła Indii (s. 215-233), którego założycielem według tradycji jest św. Tomasz Apostoł. Wyjątkowo obszernie - w porównaniu z wcześniejszymi rozdziałami - Autor przedstawia historię Kościoła św. Tomasza w czasach nowożytnych i współczesnych (s. 223-233).

Rozdział XII poświęcony jest Kościołowi ormiańskiemu (s. 234-250). Autor ukazuje historię Armenii w czasach przedchrześcijańskich, pierwszą 
ewangelizację, powiązanie wiary z tożsamością narodową oraz wpływ religii na kulturę ormiańską. P. Siniscalco - w przeciwieństwie do poprzedniego rozdziału - tylko pokrótce przedstawia późniejsze dzieje Kościoła ormiańskiego, a przecież należałoby więcej miejsca poświęcić historii Ormian na początku XX w. ze względu na ludobójstwo, które dotknęło ten naród z powodów religijnych.

Rozdział XIII przedstawia historię Kościoła gruzińskiego (s. 251-269). Autor w interesujący sposób pisze o Gruzji, łącząc jej historię z opowieściami mitologicznymi, i podkreśla, że chrześcijaństwo dla narodu gruzińskiego ma wymiar symboliczny.

Autorem rozdziału XIV, zatytułowanego Literatura patrystyczna $w$ Armenii $i$ Gruzji (s. 270-292), jest Michel van Esbroeck. Autor rozpoczyna swe rozważania od omówienia wspólnego dziedzictwa krajów kaukaskich, dalej ukazuje pojawiające się między nimi różnice, następnie zaś przechodzi do przedstawienia momentu całkowitego ich rozdzielenia. Po zaprezentowaniu powyższych treści opisuje niezależnie tworzącą się literaturę armeńską i gruzińską.

Reasumując należy powiedzieć, że książka Paolo Siniscalco Starożytne Kościoły Wschodnie. Historia i literatura jest bardzo wartościową pozycją przede wszystkim ze względu na podjętą tematykę oraz uzupełnienie pewnej luki, jaka istniała w literaturze dotyczącej historii Kościołów wschodnich. Największym atutem tej książki - moim zdaniem - jest bibliografia, która - również w języku polskim - została podana na końcu każdego rozdziału.

ks. Marcin Sobiech - Lublin, KUL

\section{Robert WIŚNIEWSKI, Wróżbiarstwo chrześcijańskie w późnym antyku, czyli jak poznać przyszlość i nie utracić zbawienia, Warszawa 2013, Sub Lupa, ss. 265.}

Nowa książka znanego historyka z Uniwersytetu Warszawskiego, Roberta Wiśniewskiego, jest przekrojową syntezą podsumowującą kilkuletnie badania prowadzone nad rekonstrukcją i oceną zjawiska wróżbiarstwa w środowisku chrześcijan późnego antyku. Autor prezentuje na podstawie zachowanych źródeł historyczno-literacko-teologicznych szeroką panoramę zagadnień związanych z nieakceptowanym oficjalnie przez chrześcijaństwo procederem wróżenia jako sposobem zdobywania wiedzy o przyszłości, który jednak występował, zwłaszcza wśród etnochrześcijan, usiłujących pogodzić go z nową religią.

R. Wiśniewski z dużą erudycją przedstawia w sposób oryginalny złożoność problemu i dokonuje nie podjętego dotąd w literaturze światowej na taką skalę usystematyzowania zagadnienia, korzystając krytycznie z rozproszonych po całej twórczości późnoantycznej tekstów źródłowych związanych z wróżbiarstwem uprawianym przez pogan i chrześcijan. Rzetelne analizy źródłowe skonfrontowane z najnowszą obcojęzyczną literaturą przedmiotu (na szczególną uwagę zasługują: wykorzystanie ostatnich badań dotyczących Sortes Sanctorum, zmieniających całkowicie sposób patrzenia na zjawisko określane tym terminem - ważna korekta 